\title{
TEACHER DEVELOPMENT AND MANAGEMENT AT SECONDARY EDUCATION IN NEPAL
}

Kedar N. Shrestha*

Abstract

Though the concept of teacher development was institutionalized in 1971, the policy of the government on this issue has not remained consistent. When the

government started its own institutions to provide inservice training to teachers, the universities started losing the government support to improve their professional programs.

As a result, the pre-service training programs gradually converted into academic and less professional program. There are issues emerging in the effectiveness of the training and the concerns how to better shape the teacher education in Nepal. This paper discusses the context and recommend measures that can bring the teacher education to the right track.

\section{Appraisal of the Teacher Development System}

The concept of teacher development was institutionalized in 1971 when the government adopted the policy that all teachers must receive 10 month training. The government also provided additional allowance for the trained teachers. But, the government could not provide the training facilities to train all the untrained teachers already working in the system. The policy of the government on the teacher development has not remained consistent. When the government removed the training allowance, serving teachers lost incentive to undergo the training program. When the government started its own institutions to provide in-service training to teachers, the universities started loosing the government support to improve its professional program. As a result, the pre-service training programs gradually converted into academic and less professional program. The expansion of in-service training conducted by the agencies of the Ministry of Education with the financial assistance of external agencies faces serious handicap. Shortage of professional staff in the government training institutions has badly affected the quality of training. A new modality of in-service training for lowersecondary and secondary teachers as described earlier has been recently adopted and implemented. The training institution has already faced the shortage of qualified trainers.

The present system of pre-service training has been pointed out to be in-operational. One cannot say that the country has a sound pre-service training system for lower secondary teachers. There is a serious need to revise the existing system and institute a sound system to train the lower secondary teachers.

Teacher Personnel Management (Recruitment, Promotion and Transfer)

Before 1971, all school teachers used to be appointed by the School Management Committees of individual schools. Government

Formerly, School of Education, Kathmandu University 
had taken no responsibility regarding the appointment, promotion and transfer of school teachers. In fact, the country did not have any rules and regulations with regard to the teacher personnel service. Teachers belonged to the individual schools, and their conditions of services were fixed by the individual schools.

In 1971, the government fixed the salary scale of school teachers and assumed the responsibility to pay the salary. A system of appointment and transfer were incorporated in the Education Regulation of the government. However, teachers were not receiving other service benefits and that caused the trade-union type struggle by the teachers demanding the equal treatment and service conditions for teachers equivalent to the individuals working in civil service. At last, the government agreed to provide all benefits to school teachers almost equivalent to the personnel belonging government civil service.

\section{Changing Recruitment Policy}

Before 1971, school teachers used to be recruited by School Management Committees. After 1971, school teachers were recruited by a district level Teacher Selection Committee. Very few teachers were recruited during 1980's. In 1990, when the MOES advertised for about 14000 teacher positions to apply for competitive written examination about 200000 candidates applied. Against the existing regulation to declare only one-third more than the available position as eligible candidates for interview, any one securing 35 marks were declared eligible for interview -the final selection process. About 86,000 candidates were declared eligible for interview for about 14000 posts. Fearing the possible manipulation in the interview, teachers unions vehemently opposed the results of written examination. The district level Teacher Selection Committee could not organize "Interview" sessions for final selection. At last, the government decided to institute a more credible system of teacher recruitment. In 1999, the government declared a new system of teacher recruitment.
Present Teacher Recruitment System

The Education Act, and its amendments (2002) has provided two types of recruitment system for the schools of Nepal. One major system which is applicable to nearly 99 percent of the nearly one hundred thousand teachers in the system which provides for Teacher Service Commission which is authorized to conduct a fixed process for the appointment and promotion of teachers of community schools. The Education Act has specified an elaborate process of recruitment of teachers in the community schools directly administered by the government. The process includes the following steps in sequence:

(a) Public notice of the vacancy and call for candidate application

(b) Notification of the eligible candidates

(c) Notification on the place and date of written examination with 100 marks and practical examination with 25 marks.

(d) Interview of those who successfully pass written examination. Interview will carry 25 marks

The government provides permanent tenure appointment to the candidates recommended by Teacher Service Commission. Teacher Service Commission is a national body with its office in the capital city of the country. Recently, the government has adopted the policy of decentralizing the management to the local school level. The government allows the individual School Management Committee to operate the schools. Such schools which are managed by the SMC are also authorized to offer permanent appointment to the teachers as shown in the table below:

\begin{tabular}{|l|l|}
\hline Type of school & Teacher appointing authority \\
\hline $\begin{array}{l}\text { A. Community schools, } \\
\text { Government Managed }\end{array}$ & $\begin{array}{l}\text { Teacher Service } \\
\text { Commission }\end{array}$ \\
\hline $\begin{array}{l}\text { B. Community schools, } \\
\text { Community Managed }\end{array}$ & $\begin{array}{l}\text { School Management } \\
\text { Committee }\end{array}$ \\
\hline $\begin{array}{l}\text { C. Corporate schools, } \\
\text { Privately Managed }\end{array}$ & $\begin{array}{l}\text { School Management } \\
\text { Committee }\end{array}$ \\
\hline
\end{tabular}


The Teacher Service Commission follows a process which includes the public notice of the vacancy, written examination of the candidates, interview of candidates who passed the written examination. Practical tests are also conducted where it is required. Private schools develop their own process of appointment.

\section{Promotion System for Community School Teachers}

Education Act and Regulation has specified the following process of promotion for the community school teachers.

A. There are three levels in each level: primary level, lower secondary level and secondary level.

\begin{tabular}{|l|c|c|}
\hline Primary Teachers & $\begin{array}{c}\text { Lower Secondary } \\
\text { Teachers }\end{array}$ & $\begin{array}{c}\text { Secondary } \\
\text { Teacher }\end{array}$ \\
\hline Class I (Highest) & I & I \\
\hline Class II (Middle) & II & II \\
\hline $\begin{array}{l}\text { Class III } \\
\text { (Lowest) }\end{array}$ & III & III \\
\hline
\end{tabular}

B. Teachers can be promoted from class III to class I through internal competition based on three criteria : (a) 30 marks for years of service, (b) 15 marks for academic qualification, (c) 15 marks for training and (d) 40 marks for performance evaluation

The Teacher Service Commission has adopted the following policy to promote the teachers in the same level: (i) Fill up the vacant position by internal promotion-written examination for 25 percent of the vacant position (ii) Fill up the 75 position by promoting the teacher on the basis of the performance evaluation.

\section{Teacher Transfer}

When the national system of teacher service was established in the process of the implementation of National Education System Plan (1971-76), teachers could be transferred by an authorized officer of the district and region level offices of the Ministry of Education. Thousands of teachers applied for transfer from the remote and less-accessible areas to urban areas. The provision of easy transfer of teachers created a menace in school management. The government adopted a policy which completely discouraged the transfer of teachers. According to the present regulation a teacher can be transferred on two conditions: (i) The teacher first has to get the approval of transfer from the school where s/he is working, (ii) The teacher should receive the approval of the school where s/he applies for transfer. Getting the approval of two schools is not easy. So, the pressure for transfer has tremendously reduced.

\section{Teacher Demand and Supply}

Nepal has been facing strange situation regarding the demand and supply of teachers. Schools are authorized to appoint teachers on temporary basis on the government approved positions. About ten years back, the government issued public notice of teacher vacancy on all three levels of teachers (primary, lower secondary and secondary). For the vacancy of primary teachers, 128303 candidates applied. Similarly, the number of application for lower secondary and secondary teachers were 51539 and 25529 respectively. There were only about 14000 vacant positions. The data indicated that supply of teachers far exceed the demand even ten years ago. The Teacher Service Commission has not published any public notice of vacancy of teacher positions during the past ten years. One can safely assume that there is no dearth of the supply of teachers.

Nepal used to face the shortage of teachers in the remote northern districts. When the government adopted the policy of paying attractive allowance for teachers working remote areas, the problem of teacher supply has considerably diminished.

The government has adopted the policy of maintaining gender parity in the teaching force. Quite a few programs have been executed to increase the number of female teachers in schools. In fact, there is a requirement that each primary school must have one female teacher.

There is some problem of the shortage of Science 
and Mathematics teacher in the schools of remote areas and some hill districts. Qualified teachers of urban areas resist to go and serve in the remote areas when they can find jobs easily in urban areas. The local communities provide additional benefit to the teachers who work in the school of such geographical locations.

\section{Career Development for Secondary Teachers}

Teacher service is a special service created by the government. The service conditions of teachers of community schools is not very different from that of the civil service of the government. Teachers service has been provided with all the perks and benefits like annual grade increase, promotion within the level, gratuity, pension etc. However, there are some limitations imposed on the teacher service. A person who enters the secondary teacher service would remain secondary teacher for life. The maximum he or she can go is the first class secondary teacher. Even if s/he is appointed a principal of a secondary school, he remains a secondary teacher. Accumulation of higher academic degrees or professional training would not help him receive higher level of status. As there is no higher secondary teacher service, a secondary teacher starts as a secondary teacher and ends as a secondary teacher.

The government of Nepal had adopted the policy of financing the school by paying the fixed percentage of the salary of teachers. In 1971, the government financed schools by paying 100\%, $75 \%$ and $50 \%$ of the salary of primary, lower secondary and secondary teachers, respectively. Later, the government paid one hundred percent salary of teachers of all levels (excluding higher secondary level). But the government never provided the financial resources required to operate a school efficiently. The government had fixed a teacher-student ratio. But, the government did not provide teachers as per the rule and policy of the government. Most schools have less teachers than required and most secondary schools did not have teachers to teach different subjects. In fact, the government did not implement a sound teacher management policy. The government went on adding the benefit to the teachers but did not add additional teachers where needed. At the secondary level absence of required teachers in required subjects is critical in operating schools efficiently. Teacher management has been implemented very inefficiently and this has its implication on the quality of education in the schools. This is one part of the story which is hardly highlighted. Teachers are always blamed for underperformance. The government of Nepal has adopted the policy of decentralization of school management by handing over the authority of school management to the School Management Committee (SMC). Again, the decentralization policy is linked with teacher management . The SMC is authorized to select and appoint the teachers of the school. The government has adopted a major change in the policy of teacher management. But, the government is yet to publish a legal document explaining the status of teachers appointed by the schools in terms of the service conditions and benefits. And, this is also a reason why teacher unions are opposed to the decentralized policy. The questions are raised: whether the teachers appointed by the schools get the benefits like pension, gratuity, medical allowance. If they would get these how will it be financed? At present, confusion exists. And, this is one reason why teachers are opposing the change in the teacher management policy.

\section{Teacher Career Development and Instructional Quality}

Teacher career development was not an agenda of educational development programs of Nepal up to 1971. Schools were established and operated by the communities with the approval of the government. Schools used to receive small token financial assistance from the government. In fact, there was hardly any teacher who joined teaching for career. In 1971, the government fixed the raised salary of teachers and assumed the responsibility to pay the salary of the teachers regularly. This system paved the way for the teachers to unite in the form of organization. The 
trade-union type struggle started continuously for the last thirty years demanding additional facilities for teachers. By 1990, teachers of community schools were given almost all the facilities enjoyed by personnel of the government civil service.

During the past two decades, quite a large number of schools have been established in the private sector. These private schools receive no financial or professional support from the government. In spite of the high tuition fees, their popularity is increasing among the parents. It is said that the gradual decline of instructional quality of community schools has been the sole reason to account for the popularity of the private schools.

Private schools known as corporate schools are fully authorized to select their own process of recruitment of teachers.

\section{Teacher Remuneration and Benefits for Community}

School Teachers and Private (Corporate) School Teachers

Since 1971, teacher positions were equated with the civil service positions of the government with the right of the teachers to receive the salary equivalent to the civil service positions. For example the position of a lower-secondary teacher is equivalent to the civil service position of non-Gaz Class I. Similarly, the post of secondary teacher is equivalent to the Gaz Class III position of civil service. A non-Gaz. Class I civil servant and lower secondary teacher receives about \$ 1200 per year. A secondary teacher and Class III Gaz officer received about $\$ 2000$ per year. They are entitled to receive the salary of equivalent positions of government civil service. Teachers are also entitled to receive the other benefits equivalent to that of civil service. Major benefits enjoyed by the teachers are: (a) 13month salary per year, (b) 10 percent addition to be deposited in service fund, (c) Pension after serving 20 years, (d) Gratuity if a person has served more than five years and less than 20 years, (e) Fixed amount of medical fund, (f) Monitory subsidy of accumulated home, sick leave and (g) Health insurance. The changes introduced by the government on these benefits are also applicable to the community school teachers.

Recently, the government has adopted the policy of handing over the management of schools to the school community. In the new decentralized system, the School Management Committees are authorized to recruit the teacher for the schools on the permanent basis. But, teachers expressed suspicion on the decentralization policy of the government to hand over school management authority to individual School Management Committees. So, the hand-over policy has been very slow.

\section{Recruitment of Teachers in Private (Corporate) Schools}

The government has legally authorized the private schools to recruit the teachers in their schools. The only government direction is that the private schools should follow the pay-scale fixed by the government. But, this direction is hardly followed by the private schools. Except very few large schools, the private schools do not pay the teachers as directed by the government. Teachers of private schools hardly get any benefit which is enjoyed by the teachers of the community schools. Mostly, private schools are operated as family business. Teachers are appointed almost on contract basis for one year. They can be dismissed by the school-proprietor at any pretext. Teachers are always at pressure to teach in school. Regularity, punctuality, emphasis in homework and student-achievement in examination are the sole indicators of teacher-efficiency. So, teaching takes place in private schools. Almost the reverse is true with public schools. Teacher accountability is almost absent in the public school. That is found to be the main reason why private school students score high in the external examination.

\section{Teacher Management and Quality of Instruction}

Nepal has a very unique experience. It is an experience which testifies that there is no 
correlation between the service benefits of teachers and the quality of their performance. From 1971 to 1991 , the government went on adding the benefit to the teachers of the community schools. It is during this duration that the quality of instruction in the community schools declined. The private schools grew during this period. Those who can pay started admitting their wards in the expensive schools. Parents accepted the results of School Leaving Certificate (SLC) as indicator of quality instruction. SLC is offered to students who successfully pass the external examination at the end of $10^{\text {th }}$ grade. The score of students in SLC examination determines his/her opportunity to enter higher level of education.

\section{Appraisal of Teacher Career Development and Instruction Quality}

Nepal has a strange experience of teacher career development and instructional quality improvement. It tells the experience with evidence that service benefits to teachers and instructional quality has no correlation. The results of SLC examination is the evidence. Take the result of SLC examination result of 2004. The pass percent of government aided community school was 37.25 when the pass percent of the private schools was 83.43 . Further only 9,203 students out of 136,904 from community schools passed in first division where as 19,480 out of 35,275 students from private schools passed in the first division. Nearly 50 percent of the teachers of government aided school have received adequate teacher training. Very negligible percent of teachers of private schools are trained. The Ministry of Education provides financial support to teachers when they are deputed for training. On the other hand, the private school teachers are not even enrolled in government operated teachers training programs.

A wide variety of training programs have been made available for the secondary teachers by the government for the past two decades. There have been short-term trainings on the teaching English language, Science and Mathematics.
But, there has been no significant improvement in the teaching of these subjects in the schools. Most students fail in English language, Science and Mathematics in the SLC examination.

The teacher personnel policy of the government for almost two decades was very liberal in terms of transfer, promotion, career development and similar other areas. When the government could not find any positive returns of this liberal policy, a change in the future policy appears in the pipeline.

\section{Findings of Research on Teacher Management and Teacher Performance}

Thirty years of teacher management has been characterized by constant struggle by the teachers for more and more benefits. Teachers were grouped under the main political parties. Their alignment with the political parties gave them enough strength to pressurize the government to meet their demands of additional benefits. Teachers continued struggle for more benefit and government's policy of offering additional benefit to teachers to meet teachers demands have dominated the educational scenario from 1971 to 1990. After the political change of 1990 , teacher management took a different turn. Both the party government and teacher unions got highly involved in using the teachers for the benefit of aligned party and the benefit of teachers. Following are some of the characteristics of the teacher related activities:

a. All major political parties made special efforts to have their teacher unions, and teachers had been enrolled in the partyaffiliated teacher unions. Teachers had been allowed to actively participate in the political activities.

b. The facility enjoyed by the teachers to get transferred was highly misused. Thousands of teachers from rural and remote areas started to pressurize the party government to get transferred to urban areas. They used the teacher unions affiliated to the 
party in power as their pressure-group. The government was so much overwhelmed by the teacher-transfer problem that they adopted a new teacher-transfer policy. The teacher-transfer authority was decentralized to school level. Now, transfer of teachers has become very difficult.

c. Another incident related to teacher management was an attempt by the government to favour the teachers of the teacher unions affiliated to the party in the government. The teacher unions belonging to the opposition parties started agitation against the government decision. For ten years, the process of teacher appointment remained in-operational. Teachers' unions expressed that they had no confidence on the District Teacher Service Commission and demanded that a national level teacher Service Commission be established. As per the demand of teacher unions, the district level Teacher Selection Committee was replaced by national level Teacher Service Commission which processed the postponed teacher appointment activities and nearly 14000 teachers got permanent tenure only after 10 years.

d. Teacher participation in politics proved a menace in the public education system. In spite of the relative attractive remuneration, the quality of instruction in the publicschools was deteriorating. Studies showed that the teacher participation in active politics is one of the reasons. In 2001, new code of conduct was approved by the government debarring the teachers from taking part in national politics as active political party candidate. Only one teachers organization is recognized by the government.

e. Studies conducted by the Ministry of Education repeatedly indicated the ineffectiveness of the instruction due to the centralized nature of administration of schools. Studies suggested school-based management as solution. Accordingly the government introduced school-based management and authorized the School Management Committee to conduct the management of school.

f. Teachers have been opposing the decentralization of school management and teachers of individual schools have been strongly discouraging the School Management Committee to take over the responsibility of managing schools from the government.

g. One major characteristic of decentralized school-based management is the decentralized teacher management. School Management Committees are empowered to provide permanent appointment to teachers in the community managed schools. The government has adopted the policy of decentralized school-based management with focus on teacher management for two reasons: (i) Teachers can be made more accountable for their tasks if the supervisors of their work are based in the school. This would help raise the quality of instruction in the schools, (ii) The national level teacher trade unions will be reduced to district level.

h. Teachers are opposing the decentralized management of schools for the following reasons:

i. The government has not produced any legal document to ensure that the teachers appointed at the school level will enjoy all the benefits which are enjoyed in the centralized management system.

ii. Teachers suspect that the school-based management system is a ploy of the government to withdraw government commitment to keep school teaching at par with civil service in terms of service security and service benefits. 


\section{Teacher Performance}

The government had adopted the policy to improve the service conditions of the teachers on the assumption that the quality of education will improve if the service conditions of the teachers were improved. The assumption proved wrong. The quality of instruction did not improve. There were some research studies conducted to study the achievement level of primary school students at the end of grade III and grade V. The findings of the study indicated that the average score of students ranged from 30 to 45 marks in different subjects. At the secondary level, the result of the School Leaving Certificate external examination conducted at the national level was the evidence. The educational scenario of the educational achievement of the students of community school is depressing. On the other hand, the achievement level of students of corporate (private) school has been relatively excellent. Parents are gradually losing their confidence on the community schools. They have shown their preference to the expensive private school.

\section{Conclusion}

Nepal has experimented numerous models of teacher development and teacher management. These experiments have been conducted to solve problems that appeared in the process of implementation of policies to raise the quality of secondary education. Nepal has learned many valuable lessons as a result of these experiments. These lessons suggest some actions to continue the effort of the government to raise the quality of secondary education through better teacher development and management system. Some of these lessons and suggestions are included in this section.

\section{A. Lessons learned:}

Thirty years of educational experiments taught many valuable lessons to the Nepalese. Even the secondary teacher related training and management have provided valuable lessons for those who are engaged in the policy making, planning, training and teacher personnel management. Some of the important lessons are as follows:

\section{a. Financial incentive in isolation cannot motivate teachers to perform more effectively to improve the achievement level of students.}

In 1971, school teachers were offered a high degree financial incentive and the government went on adding facilities to teachers. But, these incentives did not motivate teachers to perform better.

\section{b. Politicization of teachers discourages teachers to perform professionally.}

The Nepalese teachers, when divided into political groupings and started acting as the sister organizations of political parties, forgot their own role as the teachers and mentors of millions of children. This complicates the equations of teaching and learning. Educational problem becomes a complex issue.

\section{c. Centralized management of schools fails to bring the stakeholders closer to the schools resulting in distancing school community from the school.}

Such a system encourages the teachers to underperform which results in underachievement of the students.

\section{d. Adding incentives to teachers without adding accountability would not help improve the teacher performance.}

Lack of accountability of teacher has been found to be one of the major reasons for the degradation of quality of teaching in the community schools.
e. When the teacher trade-unionism rises, all attempts to improve the quality of instruction face strong resistance from the teachers.

The Nepalese teachers, in general, opposed almost all attempts by the government to improve 
the teaching learning situation in the schools. Teacher unions opposed compulsory training requirement for teachers. Teacher unions did not like the introduction of teaching license. Teacher unions opposed the decentralization of school management to the community level.

\section{f. The program of teacher training become a ritual if the process of training does not add visible teaching competency in the teachers.}

In general, teachers training provided in the universities in Nepal did not aim at producing skilled teachers. Ministry of Education operates in-service teacher training mainly to achieve the quantitative targets. Eventually, the evaluators of training program declare that there is no significant difference between the teaching of trained teachers and untrained teachers.

\section{g. Required action for school-based management:}

One of the objectives of the adoption of policy to decentralizeschool management to the schoollevel is to raise the quality of instruction of community schools. Quality of instruction in schools can be raised only when the country would be able to create the situation where trained motivated teachers would work in the system. The present legal and management mechanism does not even create a basic environment of decentralized management. The first priority should be the improvement of teacher management. Legal provision should be made to ensure that none of the existing benefits given to the teachers would be curtailed. The system of teacher accountability should be established. The school-level School Management Committees should be provided total authority and responsibility to manage the school. The task of the government should be limited to providing financial grant and professional support.

\section{h. Improving school financing system:}

So far, the government of Nepal has been basing its school financing policy on the support to pay the salary and other financial benefits to teachers. This policy should be continued even after the schools are handed to communities for management. The government financial responsibility should not be limited to paying the salary of teachers. Thorough study should be conducted to identify the minimum financial resources required for normal operation of schools to provide quality education.

\section{B. Actions for teacher development}

The teaching behavior of trained teachers in schools indicate that the existing pre-service and in-service training system needs thorough reform. The government has authorized National Education Development Centre (NCED) to operate as an apex body to advise the government on all aspects of teacher development in the country. But, NCED is not equipped with the high level professionals to discharge such important professional task. NCED does not have a mechanism to use professional institutions and individuals to develop plans and programs on teacher development.

Secondary teacher training in Nepal is at a chaotic state. The emergence of few new universities and unplanned expansion of teacher training campuses of the oldest university (Tribhuvan University) changed the total scenario of secondary teacher training in the country. Need of a body for the coordination of teacher training was felt. The government established National Centre for Educational Development within the government structure without equipping it with adequate professional staff. The new institution has been overwhelmed by the task of executing big projects to implement in-service training of primary and secondary teachers. Comprehensive studies to identify the current status of secondary teacher training should immediately be conducted to establish a basis for policy and plan formulation. Side by side, studies on the teaching behaviors of trained teachers by employing quantitative and qualitative method should also be conducted. 


\section{References}

Asian Development Bank, (1992). Appraisal of Secondary Education Development Project in Nepal, Manila, Author.

Cambridge Education Consultants, (2001). Secondary Education Development Plan. Kathmandu: Author.

Curriculum Development Centre, (1993). School Level Curriculum in Nepal. Bhaktapur: Author.

CERID, 1998. Performance Level of Grade V Students. Kathmadnu: Author.

Ministry of Education and Sports, (1971). National Education System Plan. Kathmandu: Author.

(2001). Education Act, Seventh Amendment. Kathmandu: Author.
(2005). Ministry of Education and Sports, A Glimpse. Kathmandu: Author.

, (2004). Educational Statistics. Kathmandu: Author.

, (2004). Collection of Research Reports. Kathmandu: Author.

National Centre for Educational Development, (2005). Secondary Teachers Training. Kathmandu: Author.

Office of the Controller of Examination, (2004). SLC Results. Kathmandu: Author.

SEDP/SEP, MOES, (1988). Secondary Education Perspective Plan. Kathmandu: Author.

World Bank, (1999). Critical Issues in Secondary Education, Options for Reform. Washington D.C.: Author. 